\title{
Petrogenesis Batuan Beku dan Karakteristik Kekar Tiang di Bukit Pajangan, Desa Sidomulyo, Kecamatan Purworejo, Kabupaten Purworejo, Jawa Tengah
}

\author{
Mohammad Bagus Pranata $^{1 *}$, Jenian Marin ${ }^{2}$, Yoga Aribowo ${ }^{2}$ \\ ${ }^{1}$ Exploration \& New Discovery Project, Pertamina EP, Jakarta \\ ${ }^{2}$ Departemen Teknik Geologi, Universitas Diponegoro, Semarang
}

\begin{abstract}
Abstrak
Kekar tiang di Bukit Pajangan, Desa Sidomulyo, Kabupaten Purworejo, yang dikenal sebagai Situs Pajangan, termasuk dalam Formasi Kebobutak di Pegunungan Kulon Progo. Studi kekar tiang di Situs Pajangan yang baru tersingkap pada tahun 2016 masih memerlukan penelitian lanjut yang bertujuan untuk mengetahui petrogenesis hasil magmatisme serta karakteristik kekar tiang Bukit Pajangan. Penelitian ini mencakup observasi lapangan, analisis petrografi, dan analisis karakteristik kekar tiang.

Observasi lapangan meliputi pemetaan geologi Situs Pajangan dan sekitarnya, pengambilan orientasi kekar tiang, kemiringan kekar tiang, dan pengambilan sampel batuan. Analisis petrografi dilakukan untuk mengetahui tekstur dan persentase mineral. Analisis karakteristik kekar tiang dapat mengetahui geometri kekar tiang, orientasi kekar tiang, dan arah pendinginan magma saat membentuk Bukit Pajangan.

Litologi penyusun daerah penelitian dari tua ke muda yaitu, intrusi basalt, lava andesit, breksi andesit, dan endapan aluvial. Seluruh sampel batuan di Bukit Pajangan ditentukan sebagai andesit basaltik. Orientasi kekar di daerah penelitian membentuk derajat kemiringan sebesar $0^{\circ}-45^{\circ}$, diasumsikan sebagai kemiringan magma saat mengintrusi. Magmatisme pada saat pembentukan andesit basaltik secara umum dikontrol oleh fraksinasi kristal dan pencampuran magma, sedangkan komposisi mineralnya mengindikasikan hasil aktivitas Gunung Gajah yang memiliki tipe magma menengahbasa. Karakteristik kekar tiang pada Situs Pajangan adalah tipe subdivisi kekar tiang lower colonnade dan hasil aktivitas intrusi dangkal.
\end{abstract}

Kata kunci: Bukit Pajangan, kekar tiang, petrogenesis batuan beku

\begin{abstract}
Columnar joint at Pajangan Hill, Sidomulyo Village, Purworejo District, known as Pajangan Site is part of Kebobutak Formation in Kulon Progo Mountain. Studies on columnar joint at Pajangan Site that was exposed in 2016 still require further research that aims to determine the petrogenesis of magmatism and characteristic of Bukit Pajangan joint.

This study includes field observation, petrographic analysis, and characteristic analysis of columnar joint. Field observations include geological mapping of Pajangan Site and surrounding area, rock sampling, and measurement of columnar joint's orientation and its geometry. Petrography analysis was conducted to find out texture and mineral percentage. Characteristic analysis of columnar joint will determine the geometry, orientation, and direction of magma cooling when Pajangan Hill formed.

The lithology of the study area from old to young is basalt intrusion, andesite lava, andesite breccia, and alluvial sediment. All rock samples at Pajangan Hill are determined as basaltic andesite. Joint orientation in the research area formed $0^{\circ}-45^{\circ}$ slope, assumed as the orientation of magma intrusion. Magmatism at the time of basaltic andesite formation was generally controlled by crystalline fractionation and magma mixing, while its mineral composition indicates the result of the Gunung Gajah activity which has intermediate magma. Characteristics of columnar joint at the research area showed lower colonnade type as a result of shallow intrusion activity.
\end{abstract}

Keywords: Pajangan Hill, columnar joint, petrogenesis of igneous rock

*) Korespondensi: bagusprnata@gmail.com 


\section{PENDAHULUAN}

Bukit Pajangan sebelumnya ditutupi hutan, tetapi hujan besar yang tidak berhenti selama tiga hari pada bulan Juli 2016 membuat Bukit Pajangan dan wilayah sekitarnya mengalami longsor yang sangat besar, menyingkap batuan berupa anak tangga yang terkubur. Secara administratif, Bukit Pajangan berada di Desa Sidomulyo, Kabupaten Purworejo. Sampai naskah ini ditulis, belum ada penelitian dari sudut pandang geologi mengenai kenampakan situs yang masif ini. Penelitian dilakukan dengan tujuan untuk mengetahui geologi, jenis dan petrogenesis batuan beku, serta karakteristik dan proses pembentukan kekar tiang di Bukit Pajangan.

\section{Geologi Regional}

Daerah Yogyakarta terutama bagian baratdaya hingga Pegunungan Kulon Progo merupakan daerah tinggian yang terletak dalam zona poros pematang menurut pembagian Sujanto dan Roskamil (1977) dalam Harjanto (2011). Sejumlah tinggian dan rendahan dapat dibedakan pada poros ini yaitu: Tinggian Kulon Progo, Tinggian Kebumen, Tinggian Karangbolong, Tinggian Gabon, dan Tinggian Besuki.

Stratigrafi Pegunungan Kulon Progo menurut Rahardjo dkk. (1995) tersusun dari: Formasi Nanggulan Eosen Tengah-Oligosen Awal, Formasi Kebobutak/ Andesit Tua
Oligosen Akhir-Miosen Awal, Formasi Jonggrangan, Formasi Sentolo, serta intrusi Dasit, Andesit, dan Diorit. Distribusi formasi batuan dapat dilihat di peta pada Gambar 1 .

Berdasarkan penanggalan radiometri K-Ar oleh Bellon dkk. (1988) bahwa umur batuan vulkanik di daerah Kulon Progo 42,73 \pm 9,78 jtl sampai 15,3 $\pm 0,88 \mathrm{jtl}$ (Eosen Akhir - Miosen Awal) dengan penyebaran batuan vulkaniknya ke arah barat - timur (pola struktur Jawa).

Aktivitas magmatisme di daerah Kulon Progo terjadi pada Oligosen - Miosen (Van Bemmelen, 1949 dalam Harjanto, 2011) dengan penyebaran batuan vulkanik berarah barattimur. Selama Zaman Tersier, daerah Kulon Progo diperkirakan telah mengalami deformasi paling sedikit dua kali periode fase tektonik (Bellon dkk., 1988 dan Sopaheluwakan, 1994 dalam Harjanto 2011). Pertama terjadi pada Oligosen Akhir - Miosen Awal dan periode kedua terjadi pada Miosen Tengah - Miosen Akhir yang membentuk busur magmatik.

\section{Magmatisme}

Wilson (1989) terdapat 3 proses inti yang mempengaruhi komposisi primer magma menjadi bersifat lain, yaitu:

a. Fraksinasi kristal merupakan proses separasi kristal dalam fase liquid yang menyebabkan sebagian kristal terbentuk lebih dahulu karena perbedaan kondisi yang dibutuhkan untuk membentuknya (Wilson, 1989).

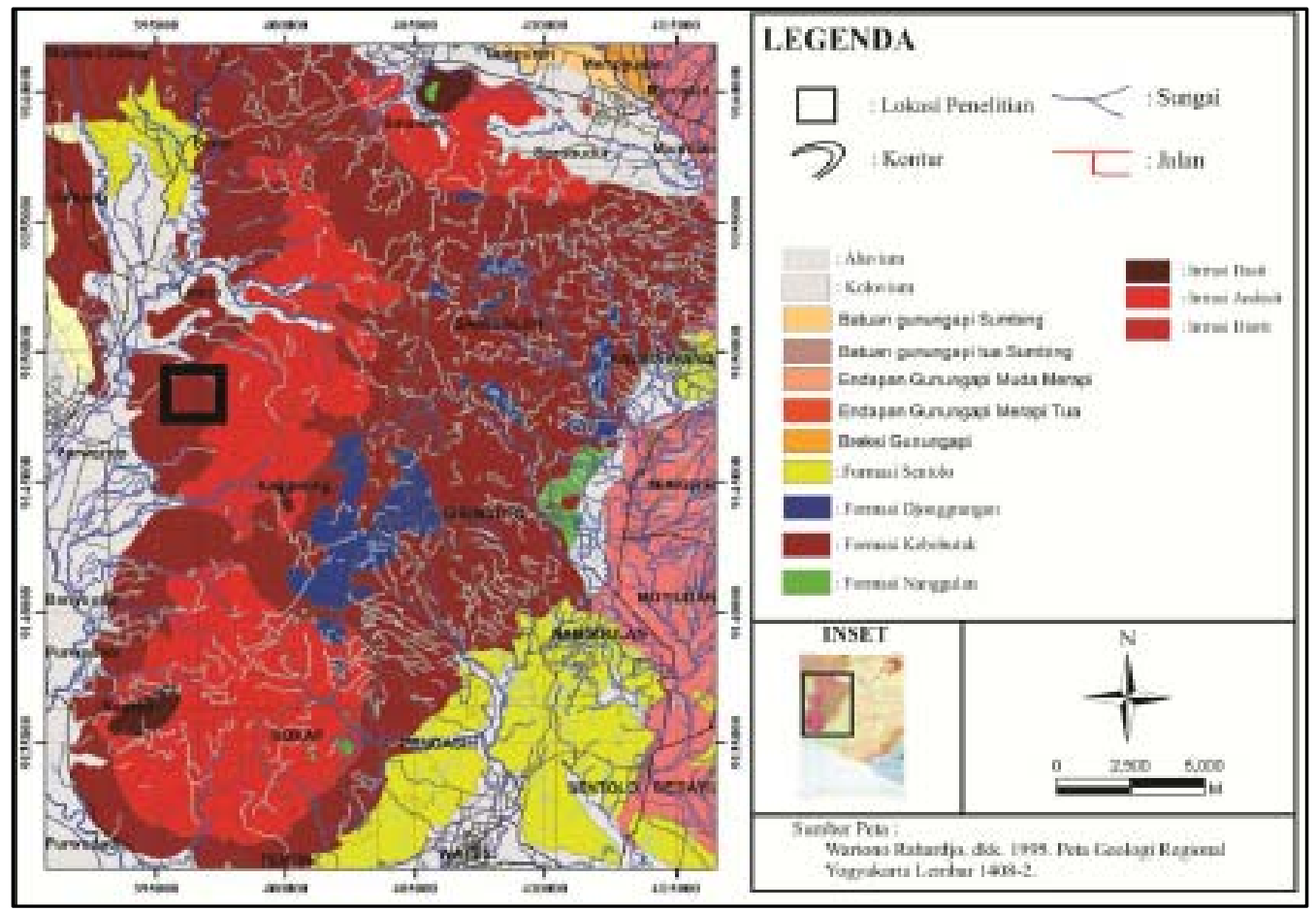

Gambar 1. Peta Geologi Regional Pegunungan Kulon Progo (Rahardjo dkk., 1995). 
b. Asimilasi adalah proses pencampuran antara magma dengan lempeng yang terjadi saat magma bergerak dari dapur magma menuju permukaan. Bila magma granitik menembus batuan gabro (mineral augit dan labradorit) maka magma tidak akan mampu mencairkan dinding tersebut. Namun, bila magma bersifat lebih basa dari batuan samping yang diterobos, maka magma akan mampu mencairkan sehingga terbentuklah batuan hybrid atau magma bersifat menengah.

c. Magma mixing diawali dengan magma primitif yang menginjeksi tubuh magma, panasnya akan ditransmisikan secara perlahan pada bagian yang terkena kontak langsung tanpa perubahan yang terjadi secara tiba-tiba. Bagian paling bawah yang tidak terkena kontak langsung akan mengalami fraksinasi dan bagian yang terkena kontak langsung akan berubah secara perlahan sehingga terjadi magma mixing.

\section{Kekar Tiang}

Kekar tiang memiliki dua karakterisik, yaitu pertama kekar tiang berupa hasil aliran lava (Wicander dkk, 2007) dan kekar tiang hasil aktivitas plutonik atau intrusif (Robinson, 1956). Menurut Spry (1961 dalam Gray, 1986), pendinginan aliran lava akan diawali dengan pembentukan rekahan hingga rekahan tersebut saling bertemu dan membentuk simpangan $\mathrm{Y}$ (Y-Junction). Semakin homogen suatu magma, maka semakin besar peluang untuk terbentuknya kekar tiang berbentuk simpangan $\mathrm{Y}$, dengan sudut sempurna $120^{\circ}$ (Gambar 2).

Dalam mempermudah memahami kekar tiang, Tomkieff (1940 dalam Gray, 1986) mengemukakan teori mengenai pembagian tiga subdivisi dari struktur kekar tiang. Aliran lava akan mengalami pendinginan yang terpisah dalam tiga zona, collonade bawah merupakan bagian pendinginan ke arah dalam atau bawah aliran, entablature merupakan bagian pendinginan dari tengah aliran lava, sedangkan collonade atas merupakan bagian pendinginan lava ke arah suhu permukaan yang paling rendah atau dingin (Gambar 3).

Arah pendinginan magma dapat diestimasi berdasarkan data arah kemiringan dan kemiringan kekar tiang. Wicander dkk. (2007) menyatakan bahwa rekahan awal kekar tiang terbentuk dari bagian permukaan dan merambat menuju ke dalam dari aliran magmanya, sehingga membentuk tiang secara paralel dengan bidang yang memanjang tegak lurus dari arah pendinginan magma tersebut.

\section{METODOLOGI}

Penelitian ini mencakup observasi lapangan dan pengambilan sampel batuan, analisis petrografi, serta analisis karakteristik kekar tiang. Observasi dilakukan dalam luasan area $3,1 \times 3,1 \mathrm{~km}$.

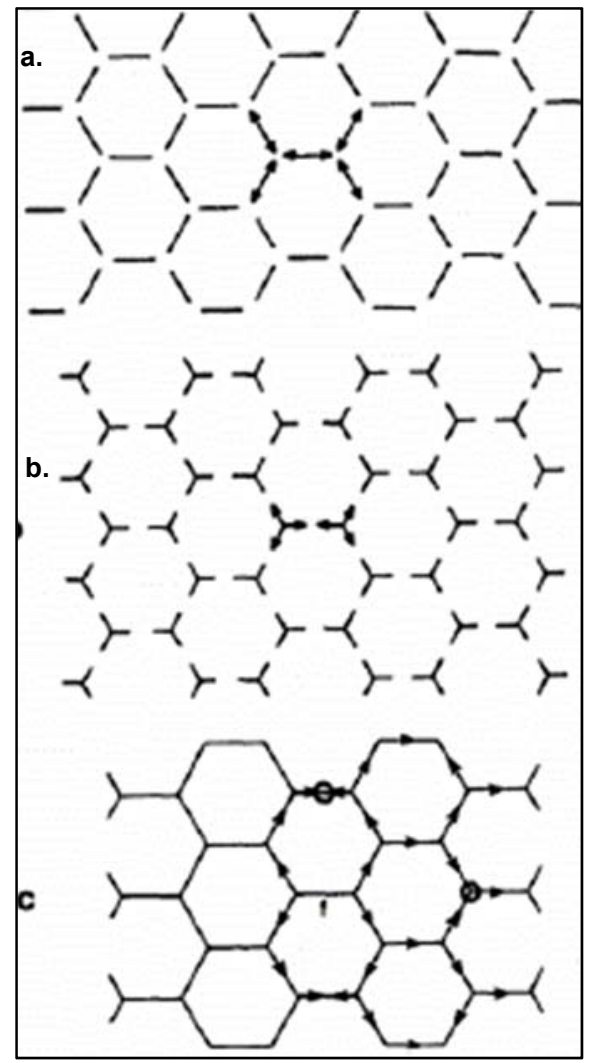

Gambar 2. a. Rekahan muncul di permukaan lava kemudian melebar hingga bertemu rekahan lain. b. simpangan Y terbentuk, rekahan kembali melebar secara radial dan bertemu dengan simpangan $\mathrm{Y}$ lainnya. c. rekahan (f) jika diskemakan tanpa ada gangguan akan membentuk pola heksagonal (Spry,1961 dalam Gray, 1986).

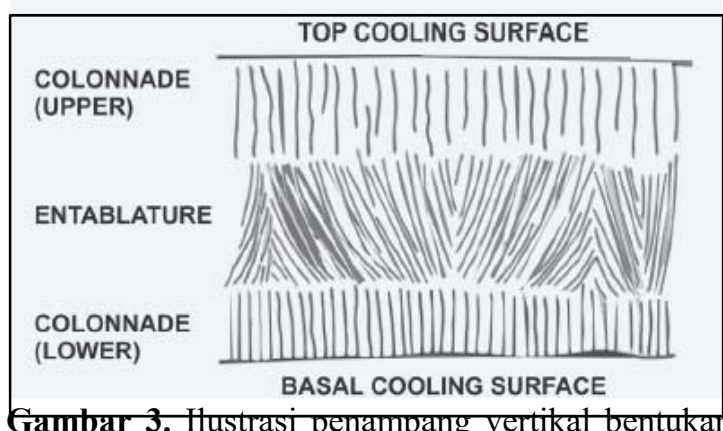

subdivisi kekar tiang pada suatu tubuh lava (Tomkieff, 1940 dalam Gray, 1986). 


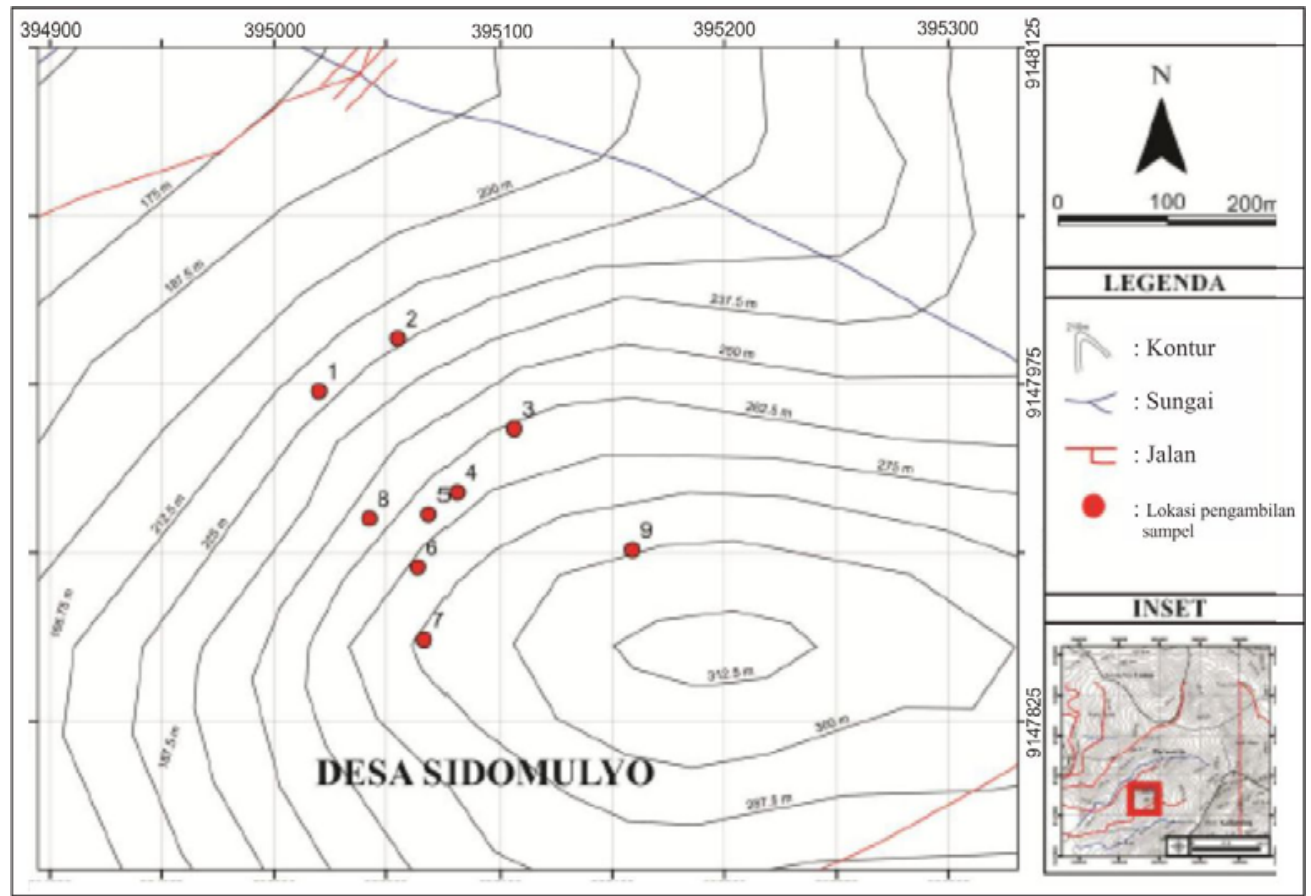

Gambar 4. Peta lokasi pengambilan sampel di Situs Pajangan.

Sebanyak 9 sampel batuan diambil dari singkapan batuan di Situs Pajangan (Gambar 4). Sampel yang diambil mempertimbangkan diameter kekar, perbedaan elevasi, dan perbedaan karakteristik batuan. Sampel dipreparasi menjadi sayatan tipis.

\section{Analisis Petrografi}

Analisis petrografi dilakukan pada sayatan tipis dari 9 sampel batuan. Analisis menggunakan mikroskop polarisasi di Laboratorium Paleontologi, Geologi Foto, dan Geooptik, Departemen Teknik Geologi Universitas Diponegoro. Penamaan batuan vulkanik ditentukan berdasarkan klasifikasi QAPF (kuarsa, alkali feldspar, plagioklas, dan feldspathoid) (Le Bas dan Streckeisen, 1991).

\section{Analisis Karakteristik Kekar Tiang}

Analisis ini dilakukan untuk mengetahui karakteristik kekar yang mencakup:

a. Geometri: diameter rata-rata kekar tiang, persentase jumlah kekar tiang dengan sudut berbeda, dan jenis subdivisi kekar tiang.

b. Orientasi: arah dan kemiringan diproyeksikan pada stereonet dan menentukan arah dominan dari trend dan plunge kekar tiang dengan software Dips V.5.1.

c. Arah pendinginan magma dapat diketahui dengan pengukuran arah kemiringan (dip direction) dan derajat kemiringan (dip) kekar tiang dan diolah dengan diagram roset.
HASIL

Observasi lapangan dan analisis petrografi menghasilkan peta geologi Daerah Bukit Pajangan dan sekitarnya (Gambar 5). Singkapan batuan beku berstruktur kekar tiang ini memiliki warna abu-abu hingga kehitaman dengan kondisi litologi terhindar dari pelapukan (Gambar 6). Struktur batuan yang diamati secara megaskopis menunjukkan vesikular dan tekstur mineral inequigranular porfiritik afanitik. Komposisi mineral penyusun batuan berdasarkan analisis petrografi dapat dilihat pada Tabel 1. Litologi penyusun daerah penelitian adalah sebagai berikut:

1) Lava Andesit. Batuan menunjukkan warna hitam kecoklatan, struktur sheeting joints, vesikular, masif, tingkat kristalisasi hipokristalin, inequigranular (porfiroafanitik). Komposisi terdiri atas plagioklas $(65 \%)$, gelasan $(15 \%)$, hornblende $(5 \%)$, mineral afanit (5\%).

2) Breksi Andesit. Warna batuan secara umum berwarna abu-abu hingga kehitaman dengan struktur masif. Karakteristik fragmen tersusun atas andesit dengan matriks berupa tuff-lapili. Tingkat kristalisasi fragmen andesit ialah holokristalin, inequigranular, porfiroafanitik. Komposisi mineral dari fragmen ialah plagioklas (50\%), kuarsa $(20 \%)$, piroksen $(8 \%)$, mineral afanit $(15 \%)$, hornblende $(7 \%)$. 


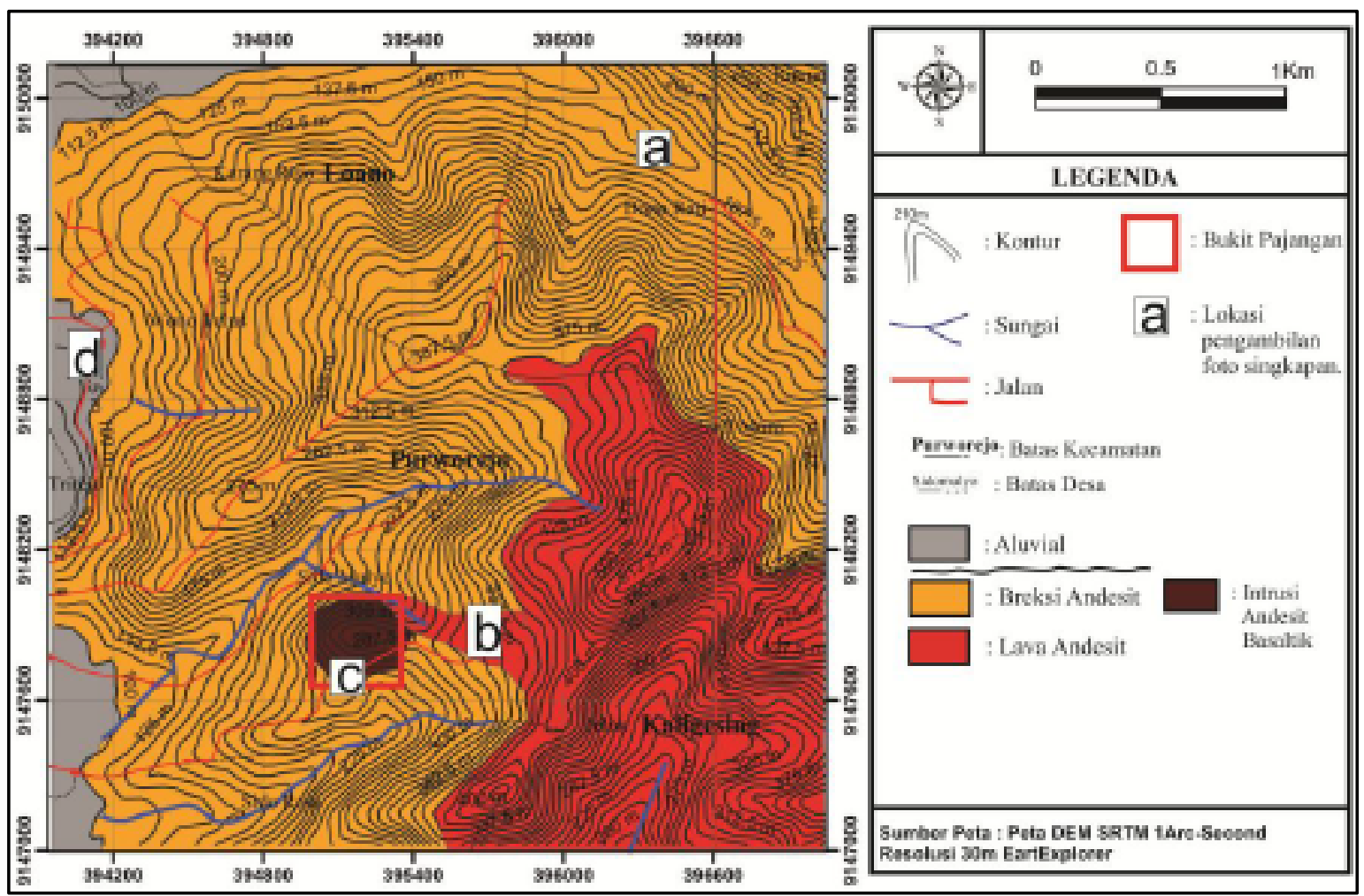

Gambar 5. Peta Geologi daerah Bukit Pajangan dan sekitarnya.
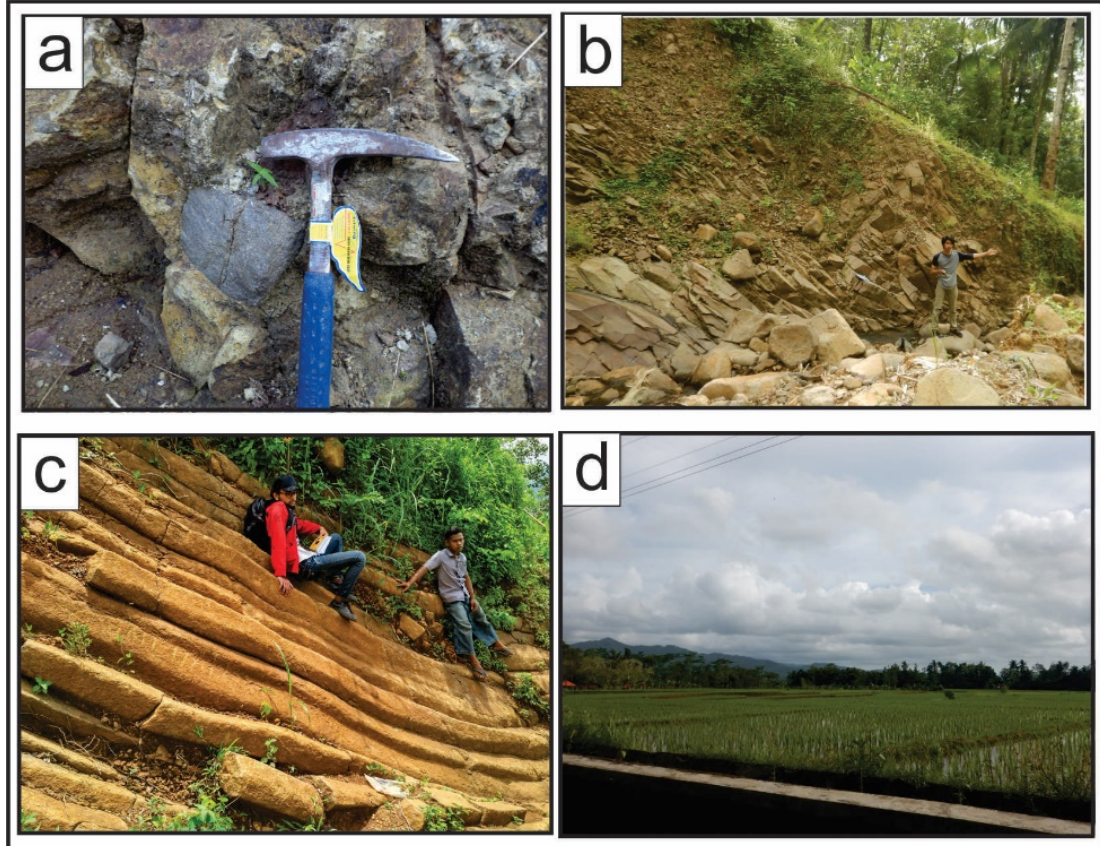

Gambar 6. Litologi daerah penelitian; (a) breksi andesit, (b) lava andesit, (c) intrusi andesit basaltik, (d) endapan aluvial.

3) Intrusi Andesit Basaltik. Warna batuan secara umum berwarna abu-abu hingga coklat dengan struktur berupa vesikular, penyebaran vesikular hanya terdapat pada bagian sisi dalam kekar tiang, sedangkan dari permukaan terlihat masif. Tingkat kristalisasi holokristalin, inequigranular (porfiroafanitik). Mineral penyusun terdiri atas plagioklas $(52 \%)$, piroksen $(11 \%)$, mineral afanit (17\%). Secara petrografi, tekstur umum berupa holokristalin dan tekstur khusus poikilitik, clots, dan zoning. Komposisi mineral terdiri dari plagioklas (68\%) berupa andesine dan labradorite, sanidin (10\%), klinopiroksen (12\%), orthopiroksen (3\%), dan mineral opak 
(5\%). Intrusi ini menembus satuan Lava Andesit dan Breksi Andesit yang telah terbentuk sebelumnya. Satuan Intrusi Andesit Basaltik dijumpai sebagai penyusun batuan berkekar tiang.

4) Endapan Aluvial. Tersusun dari kerakal, pasir, lanau, dan lempung.

Observasi di lapangan juga menghasilkan informasi mengenai geometri kekar tiang (Gambar 7). Pada Tabel 2 menunjukkan bahwa diameter rerata kekar tiang semakin kecil pada elevasi yang relatif lebih tinggi, Daerah penelitian didominasi oleh kekar tiang yang membentuk segi lima $(55 \%$ - $70 \%)$ pada semua level elevasi.

Berdasarkan statistika arah dan jurus kemiringan kekar di lapangan, diketahui bahwa kekar tiang di lapangan berarah $\mathrm{N} 328^{\circ} \mathrm{E} / 20^{\circ}$, yang juga diproyeksikan menggunakan stereonet (Gambar 8a, 8b). Arah dominan intrusi magma adalah $\mathrm{N} 58^{\circ} \mathrm{E}$ (Gambar 8c) yang relatif tegak lurus dengan orientasi dominan kekar tiang.

Tabel 1. Hasil analisis petrografi

\begin{tabular}{|c|c|c|c|c|c|c|c|c|c|c|c|}
\hline \multirow{2}{*}{ Sampel } & \multirow{2}{*}{ UTM } & \multicolumn{5}{|c|}{ Komposisi } & \multicolumn{4}{|c|}{ Tekstur Khusus } & \multirow{2}{*}{$\begin{array}{l}\text { Nama } \\
\text { Batuan }\end{array}$} \\
\hline & & $\mathrm{Pl}$ & Cpx & Opx & $\mathrm{Sa}$ & Opq & Poikilitik & Zoning & Sieve & Clots & \\
\hline 1 & $\begin{array}{l}395012 \mathrm{E} \\
9147967 \mathrm{~S}\end{array}$ & 60 & 19 & 4 & 11 & 6 & v & v & - & $\mathrm{v}$ & $\begin{array}{l}\text { Andesit } \\
\text { basaltik }\end{array}$ \\
\hline 2 & $\begin{array}{l}395048 \mathrm{E} \\
9148000 \mathrm{~S}\end{array}$ & 65 & 14 & 4 & 10 & 5 & $v$ & $v$ & $v$ & $v$ & $\begin{array}{l}\text { Andesit } \\
\text { basaltik }\end{array}$ \\
\hline 3 & $\begin{array}{l}395100 \mathrm{E} \\
9147959 \mathrm{~S}\end{array}$ & 68 & 15 & 2 & 11 & 4 & v & v & $\mathrm{v}$ & $\mathrm{v}$ & $\begin{array}{l}\text { Andesit } \\
\text { basaltik }\end{array}$ \\
\hline 4 & $\begin{array}{l}395074 \mathrm{E} \\
9147930 \mathrm{~S}\end{array}$ & 61 & 18 & 3 & 14 & 4 & v & $v$ & $\mathrm{v}$ & $\mathrm{v}$ & $\begin{array}{l}\text { Andesit } \\
\text { basaltik }\end{array}$ \\
\hline 5 & $\begin{array}{l}395062 \mathrm{E} \\
9147920 \mathrm{~S}\end{array}$ & 66 & 15 & 5 & 10 & 4 & $\mathrm{v}$ & $v$ & $\mathrm{v}$ & $\mathrm{v}$ & $\begin{array}{l}\text { Andesit } \\
\text { basaltik }\end{array}$ \\
\hline 6 & $\begin{array}{l}395057 \mathrm{E} \\
9147896 \mathrm{~S}\end{array}$ & 60 & 19 & 4 & 11 & 6 & v & $v$ & $v$ & $v$ & $\begin{array}{l}\text { Andesit } \\
\text { basaltik }\end{array}$ \\
\hline 7 & $\begin{array}{l}395060 \mathrm{E} \\
9147863 \mathrm{~S}\end{array}$ & 58 & 19 & 5 & 13 & 5 & V & $v$ & $\mathrm{v}$ & $v$ & $\begin{array}{l}\text { Andesit } \\
\text { basaltik }\end{array}$ \\
\hline 8 & $\begin{array}{l}395035 \mathrm{E} \\
9147918 \mathrm{~S}\end{array}$ & 60 & 18 & 4 & 11 & 6 & V & V & v & $v$ & $\begin{array}{l}\text { Andesit } \\
\text { basaltik }\end{array}$ \\
\hline 9 & $\begin{array}{l}395158 \mathrm{E} \\
9147933 \mathrm{~S}\end{array}$ & 65 & 17 & 3 & 9 & 6 & v & v & $\mathrm{v}$ & $\mathrm{v}$ & $\begin{array}{l}\text { Andesit } \\
\text { basaltik }\end{array}$ \\
\hline
\end{tabular}

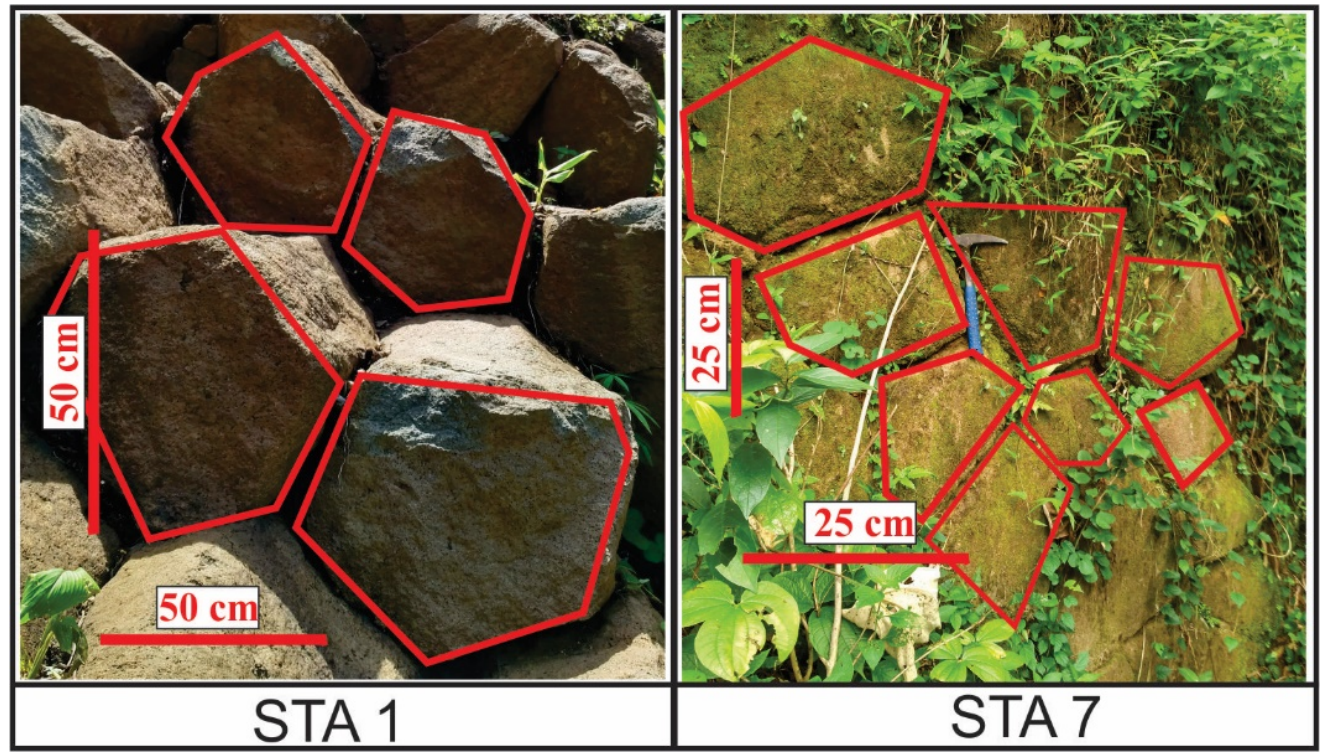

Gambar 7. Pengamatan geometri kekar tiang pada lokasi 1 dan 7 
Tabel 2. Geometri Kekar Tiang Bukit Pajangan

\begin{tabular}{cccccc}
\hline Lokasi & $\begin{array}{c}\text { Elevasi } \\
(\mathbf{m d p l})\end{array}$ & $\begin{array}{c}\text { Diameter Rerata } \\
\text { Kekar Tiang } \\
(\mathbf{c m})\end{array}$ & $\begin{array}{c}\text { Kekar Tiang } \\
\text { Segi Enam } \\
(\mathbf{\%})\end{array}$ & $\begin{array}{c}\text { Kekar Tiang } \\
\text { Segi Lima } \\
(\mathbf{\%})\end{array}$ & $\begin{array}{c}\text { Kekar Tiang } \\
\text { Segi Empat } \\
(\%)\end{array}$ \\
\hline 1 & 220 & 50 & 30 & 55 & 15 \\
2 & 224 & 45 & 30 & 55 & 15 \\
3 & 257 & 35 & 30 & 60 & 10 \\
4 & 265 & 35 & 30 & 55 & 15 \\
5 & 269 & 28 & 25 & 65 & 10 \\
6 & 272 & 35 & 25 & 65 & 10 \\
7 & 278 & 25 & 25 & 65 & 10 \\
8 & 289 & 25 & 20 & 70 & 10 \\
9 & 299 & 22 & 25 & 70 & 5 \\
\hline
\end{tabular}

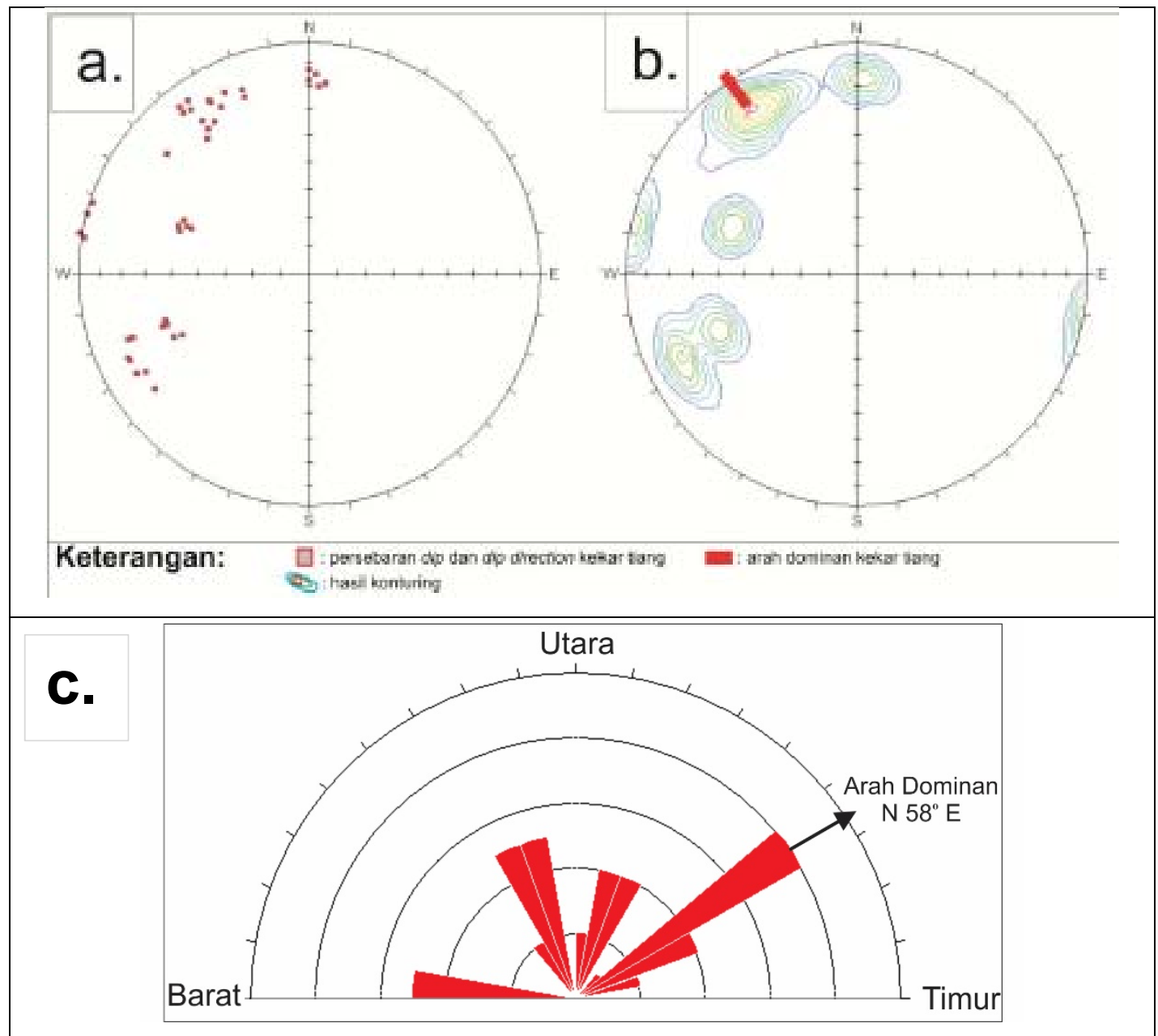

Gambar 8. a) Proyeksi jurus dan kemiringan kekar tiang di lokasi penelitian, b) batang merah menujukkan orientasi dominan kekar tiang di lokasi penelitian, c) diagram roset setengah lingkaran, arah dominan intrusi magma ditunjukan dengan skala batang berwarna merah yang paling panjang. 


\section{PEMBAHASAN}

Bukit Pajangan yang tersusun dari andesit basaltik koheren dengan komposisi batuan penyusun Gunung Gajah mengacu kepada van Bemmelen (1949) yang menyatakan bahwa material letusan Gunung Gajah berupa andesit piroksen basaltik. Penentuan umur berdasarkan K-Ar yang dilakukan oleh Bellon (1989 dalam
Harjanto, 2011) menyebutkan bahwa pusat Gunung Gajah berumur 28 juta tahun yang lalu. Dengan demikian, dapat dikemukakan bahwa magma asal yang membentuk kekar tiang Bukit Pajangan merupakan hasil dari aktivitas vulkanik Gunung Gajah pada 28 juta tahun yang lalu.

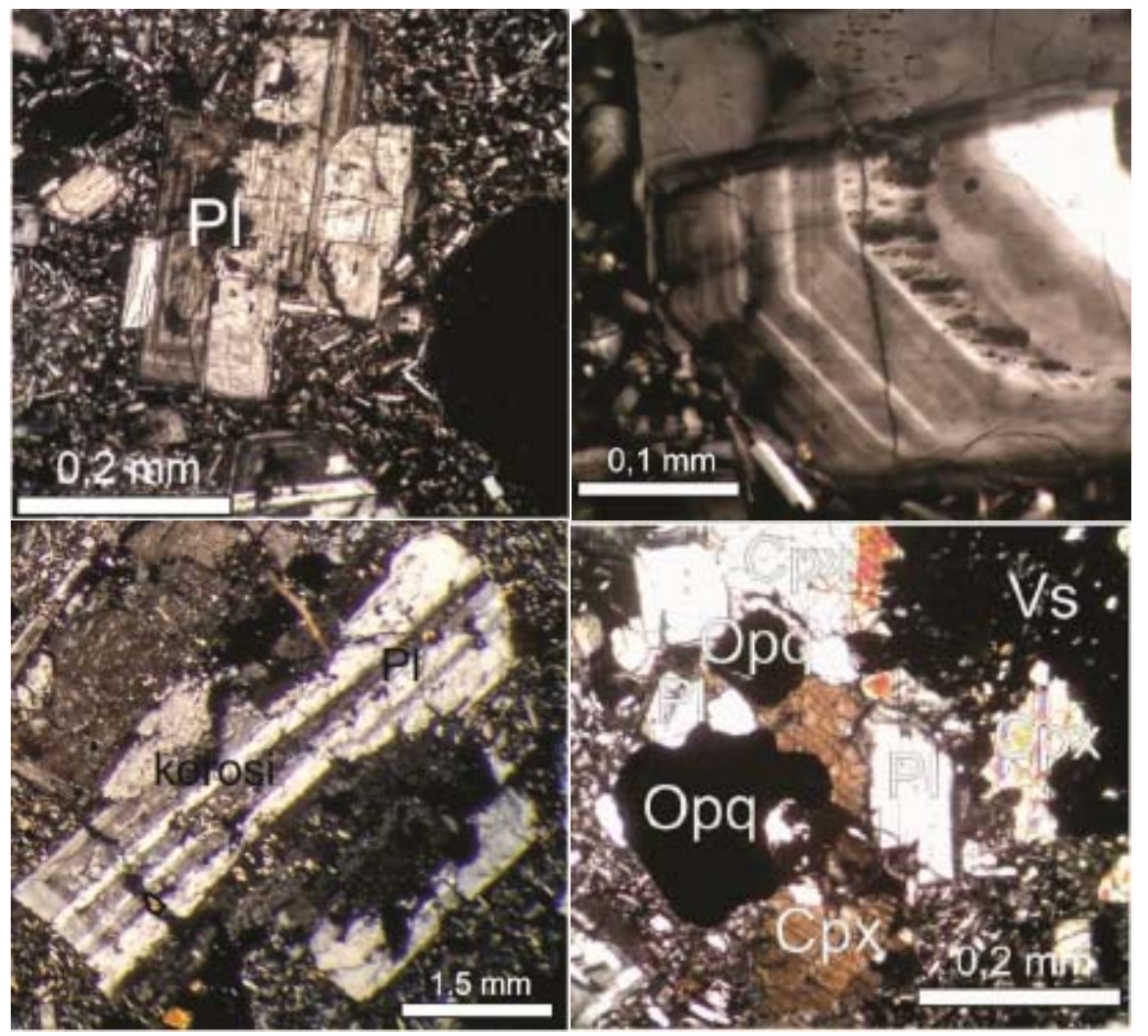

Gambar 9. a) Tekstur poikilitik pada sayatan sampel 1 (nikol bersilang), b) Tekstur zoning plagioklas pada sayatan sampel 3 (nikol bersilang), c) tekstur sieve pada sayatan sampel 2 (nikol bersilang), d) teksrtur clots pada sayatam 7 (nikol bersilang).

Secara umum, tidak dijumpai mineral dengan tekstur gelasan sebagai penyusun dari andesit basaltik di Bukit Pajangan, sesuai dengan pernyataan Wood (1986 dalam Winter, 2001) yaitu pada magma yang mendingin secara perlahan dan membentuk rekahan tidak akan dijumpai komposisi gelasan. Beberapa tekstur khusus batuan beku teramati melalui analisis petrografi, yaitu tekstur poikilitik, zoning, sieve, dan clots. Tekstur poikilitik dijumpai pada seluruh sayatan batuan, ditunjukkan dengan fenokris plagioklas dan dikelilingi mikrolit plagioklas yang mengkristal secara acak (Gambar 9a). Hal tersebut terjadi karena fenokris terbentuk terlebih dahulu yang dilanjutkan dengan mikrolit plagioklas, kondisi ini umumnya mencirikan daerah pembekuan hipabisal. Tekstur zoning juga dijumpai di semua sampel berupa kenampakan mineral plagioklas yang menunjukan pola lapisan radial mineral ke arah luar (Gambar 9b). Pola tersebut mengindikasikan pembentukan batuan beku di Bukit Pajangan terkena pengaruh aktivitas influks magma yang mengubah komposisi mineral pada bagian terluar tubuh mineral yang melingkupinya. Tekstur sieve, yaitu fenokris plagioklas yang mengalami lelehan dan mengkristalkan mineral di bagian tersebut (Gambar 9c), dijumpai hampir di semua sampel kecuali sampel 1. Tekstur ini terbentuk karena proses pencampuran magma yang melelehkan plagioklas yang sebelumnya lebih dahulu terbentuk.

Kekar di Bukit Pajangan menunjukkan orientasi arah kemiringan yang paralel. Mengacu kepada Tomkieff (1940 dalam Gray, 
1986), konfigurasi kekar yang paralel terbentuk pada lower colonnade suatu tubuh magma.

\section{KESIMPULAN}

Bukit Pajangan, secara geologi, terbentuk dari pendinginan magma yang bersifat menengahbasa menjadi andesit basaltik. Pendinginan magma berlangsung pada zona hipabisal dan termasuk bagian dari lower colonnade dari suatu konfigurasi kekar tiang. Bagian lain dari konfigurasi kekar tiang di Bukit Pajangan masih belum tersingkap. Model berdasarkan arah pendinginan magma dapat menunjukkan posisi dari bagian-bagian konfigurasi kekar tiang yang belum tersingkap di Bukit Pajangan.

\section{UCAPAN TERIMA KASIH}

Penulis mengucapkan terima kasih kepada Pak Tri Winarno, S.T., M.Eng. yang menyumbangkan buah pikiran hingga penelitian ini dapat dilakukan.

\section{DAFTAR PUSTAKA}

Bellon, H., Soeria Atmadja, R., Maury, R. C., Suparka, E., Yuwono, R. S., 1988. Chronology and Petrology of Back Arc Volcanism in Java. Proceeding of Regional Conference on Geology and Mineral Resourcees of Southeast Asia, hal. 245-257.

Gray, N. H., 1986. Symmetry in a Natural Fracture Pattern: The Origin of Columnar
Joint Networks. Pergamon Press, Ltd.: Britania Raya.

Harjanto, A., 2011. Vulkanostratigrafi di Daerah Kulonprogo dan Sekitarnya, Daerah Istimewa Yogyakarta. Jurnal Ilmiah MTG, Vol. 4.

Le Bas, M. J. dan Streckeisen, A. L., 1991. The IUGS Systematics of Igneous Rocks. Journal of the Geological Society, Vol. 148, hal. 825-835.

Rahardjo, W., Sukandarrumidi, Rosidi, H. M. D., 1995. Peta Geologi Skala 1:100.000 Lembar Yogyakarta, Jawa. Pusat Penelitian dan Pengembangan Geologi: Bandung.

Robinson, C. S., 1956. Geology of Devil Tower National Monument, Wyoming. Geological Survey Bulletin, 1021-1.

Wicander, R., Monroe, J. S., Hazlett, R., 2007. Physical Geology: Exploring the Earth, sixth edition. Thomson Publishers: Amerika Serikat.

Wilson, M., 1989. Igneous Petrogenesis. Harper Collin Academy: London.

Winter, J. D., 2001. An Introduction to Igneous and Metamorphic Petrology. Prentice Hall: New Jersey.

van Bemmelen, R. W., 1949. Geology of Indonesia. Vol. IA. Government Printing Office: The Hague. 